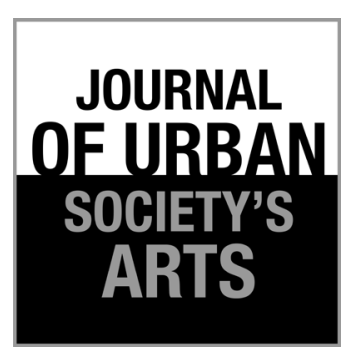

Volume 8 Number 1 , April 2021: 1-14

\section{Song Translation Analysis as a Means for Intercultural Connectivity}

\author{
Greg Aronson and Kiernan Box
}

College of Arts and Education, Victoria University

Footscray Park Campus, Ballarat Road PO Box 14428,

Melbourne, Vic. 8001, Australia

Email: greg.aronson@vu.edu.au

\begin{abstract}
In an increasingly interconnected and globalised world, the need for cross cultural understanding is greater than ever before. Exploring and analysing songs from different cultures can be an effective 'entry point' into learning about the nature of other peoples and societies lives and for developing a sense of ethnocultural empathy. Protest songs can provide a lens for intercultural analysis, especially for understanding minority or subcultural perspectives. Translating songs into different languages makes these works more accessible to a broader cross-section of people. We present translations of protest songs, two from Indonesian to English, and one from English to Indonesian. We discuss the respective importance of meaning and poetics in making song translations. Strict adherence to song rhymes is a challenge for translators and one which may impede meaning. The optimal approach depends on the format in which the translation is likely to be presented. Fluency in the target language, rather than the source language, is more helpful for successful translation. Finally, we make some recommendations about the usefulness of intercultural song (text) translation analysis and intercultural awareness.
\end{abstract}

Keywords: song translation; intercultural connectivity; ethnocultural empathy; protest song

\begin{abstract}
ABSTRAK
Analisis Terjemahan Lagu Sebagai Sarana Konektivitas Antar Budaya. Dalam dunia yang semakin terhubung dan mengglobal, kebutuhan terhadap pemahaman lintas budaya menjadi lebih besar dari sebelumnya. Mengeksplorasi dan menganalisis lagulagu dari budaya yang berbeda dapat menjadi 'titik masuk' yang efektif untuk belajar tentang sifat orang lain dan kehidupan masyarakat, dan untuk mengembangkan rasa empati etnokultural. Lagu bertema tentang pembangkangan dapat memberikan lensa untuk analisis antarbudaya, terutama untuk memahami perspektif minoritas atau subkultur. Menerjemahkan lagu ke dalam bahasa yang berbeda membuat karya ini lebih mudah diakses oleh banyak orang. Kami menyajikan terjemahan lagu bertema pembangkangan, dua adalah terjemahan dari bahasa Indonesia ke bahasa Inggris, dan satu dari bahasa Inggris ke bahasa Indonesia. Kami membahas tentang pentingnya makna dan puisi dalam membuat terjemahan lagu. Ketaatan yang ketat terhadap sajak lagu merupakan tantangan bagi penerjemah dan salah satu yang dapat menghambat permaknaan. Pendekatan yang optimal tergantung pada format di mana terjemahan akan disajikan. Kefasihan dalam bahasa target, daripada bahasa sumbernya, lebih membantu untuk keberhasilan suatu terjemahan lagu. Akhirnya, kami membuat beberapa rekomendasi tentang kegunaan analisis terjemahan lagu (teks) antarbudaya dan kesadaran antarbudaya.
\end{abstract}

Kata kunci: terjemahan lagu; konektivitas antarbudaya; empati etnokultural; lagu pembangkangan 


\section{Introduction}

Music plays an intrinsic role in the evolution of culture in various regions, communities and eras. Protest songs have a unique function, as they reflect viewpoints regarding the operation of society, including issues such as social justice, inequality, environmentalism, and rights of indigenous peoples; they frequently explore an imbalance of power between social groups. Importantly, they often express minority viewpoints, those in apposition to prevailing mainstream opinion or government policy. Further, songs have proven to be an effective tool for increasing community awareness, and stimulating community action in relation to the issues they confront. With reference to some seminal examples from Australian music, the lyrics of protest songs may be directed at general social attitudes or behaviour (Midnight Oil - The Power And the Passion 1984; consumerism and advertising), systemic patterns of behaviour (Archie Roach - Took The Children Away 1990; forced removal of aboriginal children from their birth families) or specific incidents and events (Redgum - I Was Only Nineteen 1983; Vietnam War). Such songs usually originate from a factual and existential basis, but often contain artistic embellishments and elements of fiction. Examining the content and effect of protest songs can provide an insightful window into aspects of a nation's culture, and an intercultural analysis may help interpret similarities and variances between cultures. In Indonesia, dissent or politically controversial work has frequently led to judicial or arbitrary penalty for the artist. Notably, several prominent Indonesian fiction writers including Pramoedya Toer, Mochtar Lubis, and Martin Aleida and painters such as Hendra Gunawan have been imprisoned because of the anti-establishment nature of their work or their political views. Just recently Balinese punk musician Jerinx was sentenced to jail for criticizing the Indonesian medical association's COVID19 policies. Western artists have rarely been persecuted or imprisoned for their artistic exploits, save for the occasional indecency charge or conviction.

The purpose of this paper is to employ translation and analysis of lyrics of protest songs from both Indonesian and Western cultures, as a way of better understanding cultures other than our own primary cultures. In a globalised society, where different peoples and cultures are ever more inherently intertwined, the need for greater awareness of different cultures is paramount. Respect, tolerance and understanding of other peoples can lead to the potential for desirable global outcomes such as peace and tolerance (Lasonen 2010). The specific act of translation and meaning making of Indonesian songs comes after a series of cross cultural projects between academics from Victoria University, Institut Seni Indonesia and Universitas Gadjah Mada, that were initiated in order to increase cultural, academic and artistic cooperation within the Indo Pacific region. The attempts to translate and analyse Indonesian song lyrics in this current investigation is offered as an act of deference, and as an 'entry point' to understanding another culture.

But the deference is in essence an act of understanding, no matter how dim, of the metaphoric nature of reality. The deference catches the interconnectedness of things in the other culture. It becomes the entry point into other ways of seeing things. The realisation of difference in others is always in some ways a transformation of self, not necessarily a denial of self, more usually an enlarging of self, a realisation of the potentialities of self. (Dening, 1998, p.212)

The deference, in part, also involves a starting point, an invitation to consider an activity such as song analysis and translation as an intercultural collaboration in building empathy. This exercise may lead to further projects to join in cross cultural translation and meaning making of the nature and condition of protest songs within and across cultures. These acts are ways of igniting intercultural empathy - the (beginnings) of an understanding of how others act, think and live.

The respective influence of Eastern and Western artists on each other is a vexing question and one we will only touch on briefly. According to Sen and Hill, "The music genres of Indonesia have always been syncretic and absorbed outside influences" (p165). They note that in the 1960s Indonesian music looked to American and English 
rock ' $\mathrm{n}$ roll for an inspiring sense of rebellion. Mick Jagger was a strong influence, especially on the Bandung music scene (jeger became a colloquialism for a tough, street-fighting guy, and not dissimilar to the Indonesian words jago (cock) and jagoan (champion) (p167). Indonesian psychedelic bands at this time, such as Panbers and The Brims, created music which drew heavily from Western acts such as Pink Floyd and Frank Zappa, whilst imbuing their music with strong Indonesian musical flavours and lyrics addressing Indonesian social issues. Due to its industrial scales of production and promotion, it is unsurprising that the cultural products of Western multinational corporations have had a pervasive influence in most parts of the world. Protest songs can import and absorb influences from foreign cultures, but they will only resonate authentically if the issues raised have relevance to the primary target audience, which is usually the home county of the artist.

\section{Methodology}

We propose the use of a qualitative methodology framework, utilizing the inductive method of analysing texts. In this investigation, the text (as data) are the lyrics of the songs to be analysed. Qualitative analysis is particularly useful for identifying idiosyncratic and subtle meanings within texts, such as in the case of locating meaning in music and lyrical texts. Qualitative analysis has been used effectively in analysing song texts (Czechowski et al, 2016). The primary purpose of the inductive approach is to allow research findings to emerge from the frequent, dominant, or significant themes inherent in raw data, without the restraints imposed by structured methodologies.(Thomas, 2006, p.238). Inductive coding involves a familiarisation with the text, including multiple readings and cogitation upon the array of possibilities that may be derived from the words and phrases. Translation of song lyrics, as with other text, allows for a process of close reading and familiarisation. The songs for analysis were selected in an unscientific manner. We were initially keen to translate Iwan Fals, and noticed Fernando et al.'s work comparing Fals with Bob Dylan. We used this as our own musicological entry point, researching the same two songs as these authors, and decided to add an Indonesian punk protest song for a different perspective.

Text analysis obviously involves varying degrees of semantic analysis and opinion. In most cases the argument for establishing a polemic analysis would be ultimately reductionist and therefore redundant. In text analysis the primary aim is to carefully and thoughtfully derive a series of coherent and widely understandable meanings that could be reasonably be interpreted from the text, within the opinion of the investigator. Whilst this does not mean we may pursue 'unlimited semiotic speculation' (Doll, C. 2018 p.12), we can reasonably be expected to search for meanings and make a case for the coherency and logic of those meanings. Successful interpretation of texts involves making a case that supports a particular set of meanings or a way for understanding a text, and convincing others that this is a reasonable or sound way to understand the text (Doll, C. 2018)

This search for meaning may reasonably include a hermeneutic journey. Hermeneutics is the search for meaning, for interpretation of texts, for understanding. It includes theories and approaches for interpreting texts, and has developed over time. Post enlightenment, hermeneutics evolved in humanist terms beyond literalism to include subjectivity and context, including the point of view of the author and the circumstances in which the texts developed. Employing a hermeneutic approach, in the case of analysing protest song lyrics, may reasonably include an awareness and employment of approaches that enlighten or inform meaning-making within texts that seek to make commentary upon the sociocultural conditions of a particular cultural context. The 20th and 21st century protest music - in the array of particular genres it may exist - very often seeks to voice social narratives that raise awareness of social plights particular to groups of people and to argue for ameliorations for those conditions. Hesmondalgh and Negus (2002, p.6) have repeatedly reminded us of the inherent connections between popular music and discussions of power. Therefore, this 'analytical musicology' - the search for social and political 
meaning within popular music texts - becomes a crucial role within all cultures, as Hooper reminds us, ' we need to know what it is and how to argue for it (Hooper, 2006 p. 41).

\section{Findings: Lyric Translations and Analysis}

Fernando et al (2018) argue that artistic works can reveal shared values involving love, poverty, evil, natural disasters and many other issues (p2). War is an important theme in the history of protest songs, the viewpoint usually being one of strident opposition to the conduct of war. Fernando et al (2018) conduct intercultural musicological research when they analyse and compare an American warthemed protest song, Bob Dylan's Masters Of War (1964), and an Indonesian song of similar theme, Puing by Iwan Fals (1989). They conclude that the chosen songs both reflect a view that war is a tragic occurrence, manipulatively orchestrated by powerful figures behind the scenes. Both songs use imagery of childlike objects, boneka (dolls), from Fals, little toys and play from Dylan, reinforcing the analogy that war is merely a game to those in power and control (p11). However they conclude that the songs deliver their messages with very different approaches to language. Fals' style is more persuasive and cajoling, (Eg. tolonglah tuan - please help Sir), while Dylan is highly accusatory and aggressive, the song resembling a curse he places on the warmongers (I hope that you die and your death will come soon). Where Dylan employs anger, Fals employs concern; Fernando et al argue that, for Fals, war is sheer futility, for Dylan it is truly barbaric. By comparing the mood of the two songs and the methods of their composers, Fernando et al introduce an intercultural angle to their analysis, although they do not draw any specific conclusions about the respective home societies of the two writers. Dylan's Masters Of War is a searing indictment of war mongers; with accusatory, condemning and imperative language he attacks those who incite and prosecute war without the courage to participate in the actual fighting; those who "fasten the triggers for others to fire", and "run farther when the fast bullets fly'. Fals mourns the desolate results of pointless violence and pleads for it to end. We would note that Fals does seem to change tone towards the end of the song; as if his anger builds and finally overwhelms his desire for civility, he repeatedly decries the military generals as liars (bohong).

Bob Dylan was born in Minnesota in 1941, and has been releasing music since 1962. His early work was performed in an acoustic folk style, and his original songs quickly garnered him a reputation as a hugely important and influential protest singer. He has sold millions of records, won Grammy awards and been awarded the Nobel Prize for literature. Iwan Fals was born in Jakarta in 1961 and, after an early period as a street busker, wedding musician and comedy singer, has been releasing music since 1981. Much of his music has a strong element of social commentary and protest; indeed he has been frequently labelled as "the Indonesian Bob Dylan", both in Indonesia (Swaragita 2020) and in America (Rolling Stone 2007). He was also proclaimed one of Time Magazine's 'Great Asian Heroes' (Time 2002). In 1984 he was detained by police and interrogated for 14 days, concerning the lyrical content of his songs (Rolling Stone 2011). Because of a perceived threat of crowd violence, in 1989 he was forced to cancel a 100 show tour at the order of the police (Harsono p14).

Translating songs into new languages offers a rewarding challenge to the intercultural musicologist, and one which has the clear potential to broaden and strengthen intercultural empathies. Drinker (1950) proposed a number of rules to be adhered to when translating song lyrics.

1) to preserve the notes, rhythm, and phrasing of the music;

2) to be readily singable with the particular music;

3) to be appropriate to the particular music;

4) to be idiomatic and natural English, and not merely translated German, Italian, etc.;

5) to contain rhymes wherever the music or the text calls for them;

6) to reproduce the spirit and substantially the meaning of the original.

These are all worthy aspects of translation although, as the following case studies will hopefully demonstrate, the simultaneous application of all the rules requires great dexterity and skill on the 
part of the translator. Kelly (1987) offers a similar set of rules for the song translator to follow:

1) Respect the rhythms;

2) Find and respect the meaning;

3) Respect the style;

4) Respect the rhymes;

5) Respect the sound;

6) Respect your choice of intended listeners; and

7) Respect the original.

Clearly the song translator needs to attend to a greater number of elements than the prose translator, who can focus almost exclusively on meaning, and perhaps style, with little attention required to rhythm, phrasing, sound, rhyme and singability. There is one further characteristic of song lyrics which distinguishes them from prose writing: grammar and syntax is often used in deliberately unorthodox or incorrect manner. For instance, the Rolling Stones playfully engage bad grammar to assert I can't get no satisfaction (1965). Sometimes grammar and syntax are even largely ignored, in favour of non-grammatical images and semiotic representations. Furthermore, aspects of the environments, events and characters depicted in song are frequently implied in, or even absent from, the lyric. There are often gaps and nonsequiturs in the narrative. Oemarjati (1972), discussing the work of Indonesian poet Chairil Anwar, highlights a similar difficulty of translating poetry, that there is "much less extralinguistic and situational information available to the reader than in an ordinary speech situation" (p9). Furthermore, "poems are a special type of written messages that often display their own specific characteristics, according to the literary conventions of the language used" (p9). Kurt Cobain of Nirvana escapes into impressionistic image-making in Heart Shaped Box (1994), which despite a stunning poetic effect, renders an intelligible literal interpretation very difficult:

Meat-eating orchids forgive no one just yet Cut myself on angel hair and baby's breath Broken hymen of Your Highness, I'm left black Throw down your umbilical noose so I can climb right back

The more fluid and creative use of grammar, syntax and imagery in songs can present challenges for a translator, although it can also create opportunity and flexibility, which may be needed to satisfactorily bring both the meaning and poetics of the song into the target language.

We have attempted to translate Puing into English, and a portion of Masters Of War into Indonesian. We have also translated a second Indonesian protest song, Negri Ngeri by Marjinal (2006) into English.

Translating a native source language into a non-native target language is a difficult proposition, and the unusual grammar and syntax of song lyrics, as well as their frequent use of informal language and colloquialisms, can make this task especially problematic.

If we consider the first strophe of Masters of War:

Come you masters of war

You that build all the guns

You that build the death planes

You that build the big bombs

You that hide behind walls

You that hide behind desks

I just want you to know

I can see through your masks

our attempts to convey meaning in a closely literal translation results in:

Datanglah kalian yang penguasa-penguasa perang

Kalian yang membangun semua senjata

Kalian yang membangun pesawat-pesawat kematian

Kalian yang membangun bom-bom besar

Kalian yang bersembunyi di belakang dinding-dinding

Kalian yang bersembunyi di belakang meja tulis

Aku mau kamu sadar saja

Aku bisa melihat lewat topeng-topengmu

The choice of pronouns merits consideration. Dylan uses personal pronouns you and $I$ with heavy repetition, enhancing the forthright and accusing tone of his lyric. We have chosen to use the informal and familiar aku and kamu. These are far more common in song lyrics, although it could be argued that the more formal saya and anda (perhaps even engkau or saudara) should be 
used here, not to imply respect - clearly Dylan does not respect his addressees - but to remove the familiarity and friendliness of aku/kamu; the formal versions may better convey the coldness and contempt Dylan feels for the 'Masters'. To obtain a literal translation, most of the word choices were straightforward. Death planes retains its figurative character however, with pesawat-pesawat kematian, although pesawat-pesawatpembom might be a more practical translation. We have used lewat in see through your masks, perhaps melalui, sampai even dalam could be options here.

Of course a song is designed to be sung, and a translation of a song lyric will be better if it can be comfortably sung in conjunction with the original music. Song translations of this sort have been prevalent in the music industry; the Beatles recorded German-language versions of She Loves You and I Want To Hold Your Hand in 1964, ABBA recorded several versions of their hits in French, and German band Nena released simultaneous German and English versions of 99 Luftballons in 1983; although, translated versions of pop songs are perhaps less common in the modern era.

There are further significant complicating issues when attempting to balance both meaning and poetics in a song. Our literal translation of Masters Of War would not be singable with the original music, as it has an excessive number of syllables compared to the original. Dylan's version maintains a strict meter of six syllables per line, in a mainly trochaic (stressed/unstressed) pattern. Our Indonesian version is very different in meter. The two contributing factors we observe are: firstly, Indonesian contains fewer one-syllable words than English; Dylan uses only two multi-syllable words in the whole stanza, masters and behind, whereas the translation uses 14 two-syllable words, 18 threesyllable words, and 5 four-syllable words; secondly, Indonesian plurals require duplication of the noun word, English usually just adds a non-syllabic 's' to the end of the noun. The actual word-count is very similar for both versions, Dylan's has 45 words, the Indonesian 44 (49 including duplicated plurals). However, there is a massive discrepancy in syllables; 48 for Dylan, 114 for the translation, almost triple! We are Australian students of Indonesian language, and despite best attempts, there may exist some inelegance and inefficiency in our use of Bahasa Indonesia. Nevertheless, we conclude that it is difficult to compress the intention, meaning and language of the source original into a literal translated version of comparative meter.

In order to manufacture a 'singable' translation of the first strophe of Masters Of War, modifications are required, with a primary aim of closely matching the number of syllables in each line of the original, and a secondary aim of sacrificing as little as possible of the English words' meaning. In some instances a synonym, with less syllables, may be easily transplanted (mari replaces datanglah, balik replaces belakang). All plurals have been reduced to singular; this does impact meaning, but has been deemed necessary. The crucial title word penguasa has been replaced with raja. We submit that although penguasa (ruler, authority) is a more appropriate word for the meaning of someone who controls and manipulates, raja (king) is an acceptable substitute. The figurative pesawat kematian (death plane) becomes the more literal, and shorter, pesawat pembom (bomber). Membangun (build) is replaced with the verb base word buat (make). Repetition of the personal pronoun plus relative pronoun kalian yang (you that) is replaced with the conjunction dan (and). The lengthy verb bersembunyi (hide) is omitted and becomes implied in the phrases di belakang dinding (behind the wall) and di balik meja tulis (behind the desk). Some supporting words, semua (all) and bisa (can) have been omitted. The result is a translation which adheres much more closely to the rhythmic meter of the original; there are 51 syllables compared to Dylan's 48, with each line now having just six syllables each, except for lines 6 and 8 which have seven and eight syllables respectively. The result, with its literal English translation, is:
Mari raja perang
Yang buat senjata
Dan pesawat pembom
Dan buat bom besar
Di belakang dinding
Di balik meja tulis
Ku mau kamu sadar
$\mathrm{Ku}$ lihat lewat topengmu 
Come king of war

Who makes the weapons

And the bombers

And makes the big bombs

Behind the wall

Behind the desk

I want you to be aware

I see past your mask

Rhyme is an extremely common and effective poetic device used to enhance song lyrics. There are numerous rhyme schemes (such as alternate, consecutive and inner rhymes), as well as many types of rhymes (such as perfect and imperfect, masculine and feminine, eye rhymes, wrenched rhymes, dactylic rhymes) all of which may add to the impact and appreciation of the song's language. Both Drinker and Kelly require that a song translator pay heed to the positioning of rhymes, and naturally, this creates a further dimension of complexity in such a task; it is rare that pairs of rhyming words in the source language will also rhyme when translated into the target language. In Masters of War, Dylan places rhyming words at the end of alternate lines, 2 and 4 (guns/bombs), then 6 and 8 (desks/masks); these could both be described as imperfect or 'soft' rhymes. If we wished to refine our version to include rhymes in the metrical locations used by Dylan, then more creativity and lyrical manipulation was required. Fortunately there was already a satisfactory rhyme in lines 2 and 4, with senjata and besar having last syllables from the group -a, -ah, -ar, very common word endings in Bahasa Indonesia. Lines 6 and 8 initially had meja tulis (desk) and topengmu (your mask) which clearly do not rhyme. A consideration of acceptable synonyms for these words did not produce any obvious rhyming options. A creative solution was engineered by reinstating the word for hide which had been omitted from the literal version, but using the synonym berselindung instead of bersembunyi, and replacing topeng (mask) with the rhyming pelindung (screen). Screen does not have an identical meaning to mask, yet both images can be used to represent the notion of a superficial facade. In order to re-include the 'hiding' image, one of the hiding locations, the dinding (wall) has been necessarily omitted. The result, with rhymes marked in italic, is:

\author{
Mari raja perang \\ Yang buat senjata \\ Dan pesawat pembom \\ Dan buat bom besar \\ Di balik meja tulis \\ Kamu berselindung \\ Ku mau kamu sadar \\ $\mathrm{Ku}$ lihat lewat pelindung \\ Come king of war \\ Who makes the weapons \\ And the bombers \\ And makes the big bombs \\ Behind the desk \\ You are hiding \\ I want you to be aware \\ I see past your screen
}

This version offers a translation which can be sung with the original music, and rhymes at the syllables intended by Dylan. There has however, been some unavoidable distortion of the literal meaning of the original. The viability and authenticity of this translation is therefore, clearly, contentious and should be treated with some caution. Hopefully the three versions of Masters Of War provided here demonstrate the inherent struggle between meaning and poetics when translating songs. We submit that the purpose is of crucial importance. The manner and style in which the translation is designed to be presented should strongly influence the translation choices. If the purpose is to sing the words in synchronicity with the original source music, then a greater emphasis should be applied to poetics. If the purpose is to simply analyse and discuss the lyrics in a musicological context, then a more literal translation will be more useful. If the purpose is to be presented as poetry, either as oral recitation (without the strict requirements of a fixed musical rhythmic meter) or as written verse, then perhaps a version which incorporates both literal and poetic elements in equal weighting will be ideal. As native English speakers, we conclude that translating into English is an easier task, rather than translating from English; we conclude it is preferable to collaborate with a native speaker if the target language is not English.

Puing (1989) was included on Iwan Fals album release of the same year, entitled Mata Dewa. 
It could be considered a sequel to an earlier song with similar themes and perspectives, also entitled Puing (1981), and for this reason the song we are analysing is sometimes referred to as 'Puing 2'. The lyrics do not depict the action and progress of war, rather its aftermath; the focus is on the pengungsi (refugees) and the losses they have suffered. Compared to Masters Of War, there is a sense of detachment on behalf of the narrator; there is only one first person pronoun (nafas-ku) in the whole song. The key image is of a scrawny dog hungrily eyeing all the bones of soldiers killed in fighting. Dogs and other animals have been used before as metaphors or key images in songs about war, such as Dogs OfWar (Pink Floyd 1987), War Pigs (Black Sabbath 1970) and Rooster (Alice In Chains 1992). Oktavia and Priatna (2019) discuss the use of metaphors used by Iwan Fals in his songs, concluding that the animal motif is an important part of his social critique method; tigers, snakes, elephants, rats, cats, shrimp, dogs, crocodiles, dinosaurs, lizards, lizards, ducks, parrots and lizards all appear throughout Fals catalogue of songs. In Puing, the dog is both an observer, and a scavenging beneficiary, of war's carnage. Fernando et al argue that the dog has multi-meanings in the song; although ostensibly it appears as an observer, it is also the camouflaged representation of a 'curse' (makian). A dog often appears as a metaphor for a curse in Indonesian culture; the dog's anger and unusual reaction, making a 'harsh clicking sound' with its tongue (berdecak keras beringas), may be interpreted as a societal condemnation of the horrors of war (Fernando p5).

An interesting aspect of the lyric, and one which contrasts with Masters Of War, is Fals' predominant focus on the victims of the war: dead soldiers, refugees, survivors. The bridge section is a harrowing catalogue of war's casualties. There are some allusions to the perpetrators of war (notably in the chorus), and in the latter part of the song he lambasts the military generals and the scientists who engineer destruction, but the victims have centre stage. The earlier Puing song also follows a similar arc, with vivid depictions of war's terrible repercussions populating the bulk of the lyric, only the final stanza an enraged outburst at the unbridled militarism and technology which has led to this slaughter. Masters of War, with its vituperative curse, is directed almost entirely at the propagators of war; the victims and the destruction is rarely mentioned explicitly.

Our translation of Puing attempts to capture the meaning, cadence and 'singability' of Fals' lyrics. Following a similar process to Masters of War, we began with a mainly literal translation; this time however, we were able to translate using a comparable number of syllables per line, with minimal distortions to the meaning, Perhaps the most contestable word here is the choice of $\operatorname{sir}$ for tuan, a word which implies respect and obedience. Other options would include mister or even master (which Dylan manages to use without even a hint of obsequiesence). Here is a sample of our initial translation, the fourth stanza:

Bosankah telinga tuan

Mendengar teriak dendam

Jemukah hidung tuan

Mencium amis jantung korban

Sir have your ears become bored

Hearing the cries of revenge?

Sir is your nose sick and tired

Of the putrid smell of the corpses' hearts?

To improve the singability of the translation, we then revised our work to incorporate rhyme. This stanza uses a monorhyme scheme, with a rhyming syllable at the end of each line (marked above and below in bold); some of these rhymes, both in Indonesian and English, are 'soft', with similar rather than identical syllables. We have massaged the words and their meanings to include English rhymes at the same metrical points as the original, while preserving the essential meaning of the original. In fact we have created two possible translations for this stanza, each employing a different syllable for the monorhyme. These quite different versions perhaps indicate the subjectivity, creativity and potential for error involved in making workable poetic translation of song lyrics.

Option 1

And Sir do your ears never cringe

At the shrieks and the cries for revenge?

And Sir do you not smell the stench

Of the corpses and hearts, so intense? 
Option 2

And Sir have yours ears had enough

Of the shrieking revenge, yes they must

And Sir does your nose feel disgust

At the stench of victims in the dust

In the act of shoe-horning rhymes into the English, we can detect discrepancies in meaning. Bosan (bored), suggesting apathy, does not mean the same as cringe, which suggests revulsion. Similarly, jemu (sick and tired of, fed up with) does not mean the same as disgust. They have associated meanings, but in these cases it is the pursuit of an acceptable rhyme which is prompting the word choice. In Option 2 we have not included either description (sick and tired, disgust) of the addressee's reaction to the smell, instead suggesting that he is incapable of smelling anything, due to an uncaring disposition. Dust (debu) is not mentioned in the original, but we have added this as a battlethemed location for the corpses. Again, rhyme is the overriding factor here.

\section{Puing}

1. Perang perang lagi

Semakin menjadi

Berita ini hari

Berita jerit pengungsi

2. Lidah anjing kerempeng

Berdecak keras beringas

Melihat tulang belulang

Serdadu boneka yang malang

3. Tuan tolonglah tuan

Perang dihentikan

Lihatlah ditanah yang basah

Air mata bercampur darah

4. Bosankah telinga tuan

Mendengar teriak dendam

Jemukah hidung tuan

Mencium amis jantung korban

\section{Bridge}

Jejak kaki para pengungsi

Bercengkrama dengan derita

Jejak kaki para pengungsi

Bercerita pada penguasa

Tentang ternaknya yang mati

Tentang temannya yang mati
Below is our full translation of Puing, with all rhymes matched. We have preferred and retained Option 1 from the choices for the fourth stanza. It should be noted that the rhyming patterns used by Fals are not consistent throughout the song; verses 1,4 and 6 use a monorhyme, verses 3 and 5 consecutive rhymes, verse 2 mainly inner rhymes, while the bridge and coda sections use repetition but not rhyming. This lack of rhyming structure here means it is debatable whether our translation actually requires adhesion to the rhymes which do appear - if the composer is not fussed about the consistent placement of rhymes, then why should the translator be? Nevertheless, in the interests of the integrity of the poetics of the translation, we have aimed to maintain the positioning of Fals' rhymes throughout. We have used different translations for the line Perang perang lagi in verses 1 and 5, in order to permit an acceptable rhyme in the subsequent line (War again it's war/Happening more and more; War it's war again/Will we ever see it end?).

\section{Ruins}

War, again it's war

Happening more and more

The news of the day in uproar

Refugees filling the shore

The tongue of a scrawny dog

Clicks very loudly, profoundly

At the bones he stares everywhere

Poor soldier dolls, so unfair

Sir I am asking you please

Stop this war make it cease

Look at the earth soaking wet

With blood and the tears of regret

And Sir do your ears never cringe

At the shrieks and the cries for revenge?

And Sir do you not smell the stench

Of the corpses and hearts, so intense?

Footprints of the survivors

Chattering of the disaster

Footprints of the survivors

Telling a tale to the master

About their animals who are dead

About their friends who are dead 
Tentang adiknya yang mati Tentang abangnya yang mati Tentang ayahnya yang mati Tentang anaknya yang mati Tentang neneknya yang mati Tentang pacarnya yang mati Tentang ibunya yang mati Tentang istrinya yang mati Tentang harapannya yang mati

5. Perang perang lagi Mungkinkah berhenti Bila setiap negara Berlomba dekap senjata

6. Dengan nafsu yang makin menggila Nuklir pun tercipta (nuklir bagai dewa) Tampaknya sang jenderal bangga Dimimbar dia berkata:

Coda

Untuk perdamaian (bohong)

Demi perdamaian (bohong)

Guna perdamaian (bohong)

Dalih perdamaian (bohong)

Mana mungkin

Bisa terwujudkan

Semua hanya alasan

Semua hanya bohong besar

For several decades punk has provided a potent musical vessel for lyrical messages of social critique. As a complement to aggressive, distorted guitars and urgent, pounding rhythms, punk lyrics often take the form of staccato semi-shouted lines with relatively few syllables, and this approach has helped deliver many effective protest songs. Wallach (2008) discusses the growth of Indonesian punk music in the 1990s, as it became a powerful interpretant of social injustice and inequality in Indonesian society (p113). Renowned Indonesian punk rock band Marjinal, who formed out of the homeless street-children of Jakarta, the anak merdeka, present a direct and confrontational lyric with Negri Ngeri (2006). The fast, heavily accented music and the band's image of tattoos and mohawk haircuts naturally adds further layers to this confrontationalism. Thematically, the lyrics can be interpreted as a critique of social and financial
About little brothers who are dead About big brothers who are dead About their fathers who are dead About their children who are dead About grandparents who are dead About their lovers who are dead About their mothers who are dead About their wives who are dead About their hopes which are dead

War, it's war again

Will we ever see it end

When each nation does embrace

The never-ending arms race

With a lust grown more demented

Nuclear was invented

(nuclear is god)

And the general so contented

To the crowd misrepresented:

"For peace (lies)

For the sake of peace (lies)

Used for peace (lies)

An excuse for peace" (lies)

How can it be

Things have come to this

Everything is just an excuse

Everything is just a big fat lie

inequality in Indonesia. There is a heavy focus on the plight of disadvantaged members of society; it is interesting to note that although there is a strong implication of the presence of a ruling class who subjugate the disadvantaged, they are not referred to ostensibly. The coda's exclusive use of passive di- verbs exemplifies this approach. The lyrical phrasing often includes inner rhymes, and we have adhered to this wherever possible. We have only maintained the specific syllable of rhyme within discrete sections of the song, even where the original lyric extends the rhyme across different sections. Marjinal use an -a or -ah syllable as the basis for rhyme in verses $1,2,4,5$ and the chorus. We have employed different rhyming syllables for each of these sections (-ee, -eeve, -ile, -ar and -ear), so that each section of the song has rhyme in the correct places, but not an identical rhyme throughout; to have the same syllable rhyme in all of these sections 
would be very difficult and perhaps beyond our own translational abilities. The song title is a part of the translation. In this case we wanted to preserve

\section{Negri Ngeri}

\section{Lihatlah negeri kita} Yang subur dan kaya raya Sawah ladang terhampar luas Samudera biru

2. Tapi rataplah negeri kita Yang tinggal hanyalah cerita Cerita dan cerita, terus cerita (cerita terus)

Chorus

Pengangguran merebak luas Kemiskinan merajalela Pedagang kaki lima tergusur teraniaya

3. Bocah-bocah kecil merintih melangsungkan mimpi di jalanan Buruh kerap dihadapi penderitaan

4. Inilah negeri kita Alamnya kelam tiada berbintang Dari derita dan derita menderita ...(derita terus)

5. Sampai kapankah derita ini (au-ah) Yang kaya darah dan air mata Yang senantiasa mewarnai bumi pertiwi Coda

Dinodai

Dikangkangi

Dikuasai

Dijajah para penguasa rakus

Dinodai

Dikangkangi

Dikuasai

Dijajah para penguasa rakus

The requirement of rhyme at times leads to awkwardness in translation. Occasionally this occurs in a poetic sense. Money is a 'wrenched' rhyme with free, the stress being on mon- rather than -ey. More often it is in the resultant meaning. In Indonesian, verse 2 has a sense of futility and ennui with the repetition of cerita (story); in translation a rhyme could not be found to pair with line 1 (kita) and instead a quartet of words (grieve/believe/weavel the anagrammatic pun (Negri Ngeri - Shocking Nation) as best we could, and satisfied ourselves with the synonymical Nation Damnation.

\section{Nation Damnation}

Come and see our nation free

Land so fertile, full of money

Rice fields spread wide

The ocean blue

But please, our nation you grieve

Which remains only make believe

Fables they weave, made to deceive

Unemployment everywhere

Poverty too for thousands of miles

Street-sellers are bullied and exiled

Little boys and girls are groaning

Living their dreams on the street corners

Laborers, workers bearings all of life's traumas

Here we are, this nation of ours

There are no stars, everywhere is dark and gloomy From suffering and suffering we suffer so far (we suffer so far)

How many years will we suffer severely

Rich with the fear, blood and the tears

Forever they smear this damned motherland

Tainted

Taken by force

Repressed

Colonized by avaricious rule

Tainted

Taken by force

Repressed

Colonized by avaricious rule

deceive) was patterned through the verse to replace the rhyme and repetition of the original. In verse 4, the translation we suffer so far lacks the sting of derita terus (the suffering goes on), the compromise made in search of a rhyme. We conclude that where meaning is difficult to preserve, or even the necessary level of intensity or subtlety is compromised, then the translator should consider abandoning the rhyme in favour of stronger meaning. Without 
its rhymes a song may be diminished; without its meaning it will be misrepresented.

\section{Discussion}

The artistic and musical depth of any culture is overwhelming to those unfamiliar with it. This exercise of lyric translation and analysis can only be understood as a very early touchpoint for making any meaning of the nature of the culture being explored. But, as Dening (1998) points out, the gesture is one of deference - an opening and respectful attempt to begin a conversation that might germinate into more discussion and growth in understanding of one another's cultures. What can be said about our initial, cursory investigations into Indonesia protest music, and about comparisons with this material with Western protest music, is that further investigations may indeed provide a rich opportunity for intercultural understanding. We may, for instance, discern some interesting variation in the tone between Indonesian and Western protest music. All of the songs we analysed address power imbalances, but Fals and Marjinal focus their lyrics almost entirely on the victims, the oppressed, the disadvantaged. Dylan focuses squarely on the oppressors, the privileged. Fals uses more polite and persuasive language; Marjinal writes more with passive sentence construction; Dylan is quick to reach for imperative commands. We may conclude from this a certain sense of power and privilege in Western protest music that see their provocateurs possessed with an inherent belief that their words will be heard and assist in bringing about real change. We may speculate upon the different capacities of Indonesia and Western protest musicians to 'speak their mind' without fear of retribution or consequences. Incidences of persecution and punishment towards creative persons in Indonesia, who query or attack institutions of authority, suggests that courage, determination and resilience are necessary characteristics of the Indonesian protest singer; a Western artist does not face concomitant threat. We might also speculate upon the relative commercial imperatives of Western music, including folk music, that aims to voice stories of protest but also make a splash in the commercial music markets. And this, in turn, raises the question about the commercial (as opposed to socio-political) motives of Indonesian protest singers. There are other questions arising from the post-colonial stati of Indonesian and American, or Australian, societies that have the ability to impact the tone and nature of the protest music being made. These questions may allow us to speculate upon the more precise nature of suffering, consequences of war and oppression in different cultures, with different histories, different levels of global power and different socioeconomic realities.

To be clear, we cannot make superficial or generalised assumptions about whole cultures, and the people who create those cultures, from the analysis of a few protest songs. That is not our goal or expectation. As these songs represent a mere fragment of their respective bodies of work, we should not even make strong assumptions about the selected artists. What we can do is realise the enormous opportunity there is in engaging in provocative and genuine investigations of music through collaborative and cross cultural lenses. The exercises at the heart of this investigation have been undertaken in order to explore whether it is of benefit in pursuing a wider discussion around the use of song analysis (cross culturally) as a way of understanding other cultures and growing ethnocultural empathy. We submit that such an exploration may be of value in striving for intercultural understanding. One result of the song analysis was that we are hugely keen to learn more about the music and philosophies of Iwan Fals and Marjinal.

Globalisation is a complex and multifaceted series of interactional issues for all cultures and societies. Social, economic and political landscapes do not exist equally for all people and nations. Learning about different cultures through immersive experiences, such as art and music, can provide an important comparison to some of these varied conditions among nations (Di Iorio, 2009). Confrontations with the human face of economic inequality, such as is omnipresent in many parts of developing nations, indeed as well as some parts of so called developed nations, can be fraught. Diving deep into the art and cultures of the 'other' 
allows us valuable opportunities to 'feel with others' (Guntersdorferand and Golubeva 2018, p. 56). This is an essential part of establishing empathy with all human beings, from all cultures, not just those with whom we are immediately familiar. This process can then assist in developing more complex and nuanced personal identities; identities who are more adept in evolving cultural sensitivity and awareness (Zhao, 2009). Ethnocultural empathy involves learning to negotiate the cognitive dissonance of existent beliefs with newly emerging ideas and values. Learning about cultures through music and lyrics can be a useful way for massaging this difficult process. If the dissonant states of self can be managed though close examinations of the artistic output of those we seek to better understand, we may develop more innovative and refined ways of intercultural awareness. (Keith, 2017). Belief systems are constructed through monocentric cultural experiences. Thus, the 'world' can be conceptualised as it is perceived and experienced in one's own little part of it. Immersive experiences in other cultures offer opportunities to alter these perceptions and understand that the world is vastly complex and different for all individuals.

\section{Conclusion}

Australia has a tantalizingly close geographical relationship with Indonesia. Sadly, cultural, business and political relationships between the two nations have shown less intimacy. Australians continue to maintain tighter bonds with nations and people of European descent. It is rare that Australians would listen to Indonesian songs, except for the tourist-friendly Javanese or Balinese Gamelan music. As academics with an interest in Asian music and culture; as researchers invited to present at this conference; as students of Indonesian language; as coordinators of university study tours to Yogyakarta, it was exciting and insightful to use examples of protest songs to explore and compare Western and Eastern culture. The attempts to translate the songs into the language of the other allowed us deeper insight into the motivations and of the writers, and the nation-cultures to which they belong. If translated versions of songs were more widely available, this could perhaps be one arrow in the quiver of intercultural connectivity. A publication of song translations (Indonesian to English, or vice versa, even both!) could be an exciting project for linguists and musicologists alike.

\section{References}

Czechowski, K., Miranda, D. \& Sylvestre, J. (2016). Like a rolling stone: A mixed-methods approach to linguistic analysis of Bob Dylan's lyrics. Psychology of Aesthetics, Creativity, and the Arts, 10, 99-113.

Dening, G. (1998) 'Empowering Imaginations', Readings/Writings, Melbourne University Press, 1998:212. First published in The Contemporary Pacific, 9, 1997: 419-30.

Di Iorio, A., Cerotti, P. \& Richardson, J. (2009). The Preparation of Students for a Global Career: An Innovative Study Tour Program that provides an Equitable and Inclusive Learning Experience for Students that Advances the Development of their 'Global Passport'. International Journal of Learning, 16, 89-104.

Doll, C. (2018). Some practical issues in the aesthetic analysis of popular music. In: Scotto, C., Smith, K. M. \& Brackett, J. (eds.) The Routledge Companion to Popular Music Analysis : Expanding Approaches. Milton, United Kingdom: Taylor \& Francis Group.

Drinker, H. (1950) On translating vocal texts. The Musical Quarterly, 225-240.

Fernando, R., Hasanuddin, W.S. and Hayati, Y (2018), Kritik Sosial Perang Dalam Lirik Lagu Iwan Fals Dan Bob Dylan, Jurnal Bahasa Dan Sastra 5:2.

Harsono, A. (1989), A star is banned, Inside Indonesia, December 1989 pp14-15.

Guntersdorfer, I. \& Golubeva, I. (2018). Emotional intelligence and intercultural competence: Theoretical questions and pedagogical possibilities. Intercultural Communication Education, 1, 54-63.

Hooper, G. (2006), The Discourse of Musicology (Aldershot, England; Burlington, VT: 
Ashgate, 2006), 41-72.

Hesmondalgh, D. and Negus, K. eds., (2002). Popular music studies. Oxford University Press.

Keith, D. R. (2017). Study-Abroad in Music Therapy: Cultural Immersion as a Form of Self-Experience. Music Therapy Perspectives, 35, 230-238.

Kelly, A. (1993) Translating French Song as a Language Learning Activity, Traduire et interpreter Georges Brassens: pp. 91-112. This collective volume is no 22/1-2 \& 23/1 (19921993) of Equivalences, Bruxelles: Institut supérieur de traducteurs et interprètes: pp. 91-112.

Lasonen, J. (2010). Internationalization Of Higher Education: A Case Study On College Music Teachers' Intercultural Expertise. 40, 39-50.

Low, P (2008) Translating Songs that Rhyme, Perspectives: Studies in Translatology, 16:12, pp. 1-20.

Oemarjarti, B. (1972). Chairil Anwar: The Poet and His Language. Brill.

Oktavia, W. and Priatna, A.W. (2019), Metafora dan interpretasi kritik sosial dalam masyarakat pada album lagu Iwan Fals, Jurnal Kata : Penelitian tentang Ilmu Bahasa dan Sastra Volume 3, Nomor 1 pp. 15-22.

Sen, K. and D. T. Hill (2007). Media, Culture and Politics in Indonesia, Equinox Pub.

Swaragita, G. (2020), Novel inspired by Iwan Fals' songs marks legend's 45th anniversary in music, The Jakarta Post 4/9/20 https://www. thejakartapost.com/life/2020/09/04/novelinspired-by-iwan-fals-songs-marks-legends45th-anniversary-in-music.html.

Thomas, D. R. (2006). A General Inductive Approach for Analyzing Qualitative Evaluation Data. American Journal of Evaluation, 27, 237-246.

Wallach, J (2008), 'Living the punk lifestyle in Jakarta', Ethnomusicology, vol. 52, no. 1, University of Illinois Press, pp. 98-116.

Zhao, Y., Meyers, L. \& Meyers, B. (2009). Crosscultural immersion in China: Preparing preservice elementary teachers to work with diverse student populations in the United States. Asia-Pacific Journal of Teacher Education, 37, 295-317. 